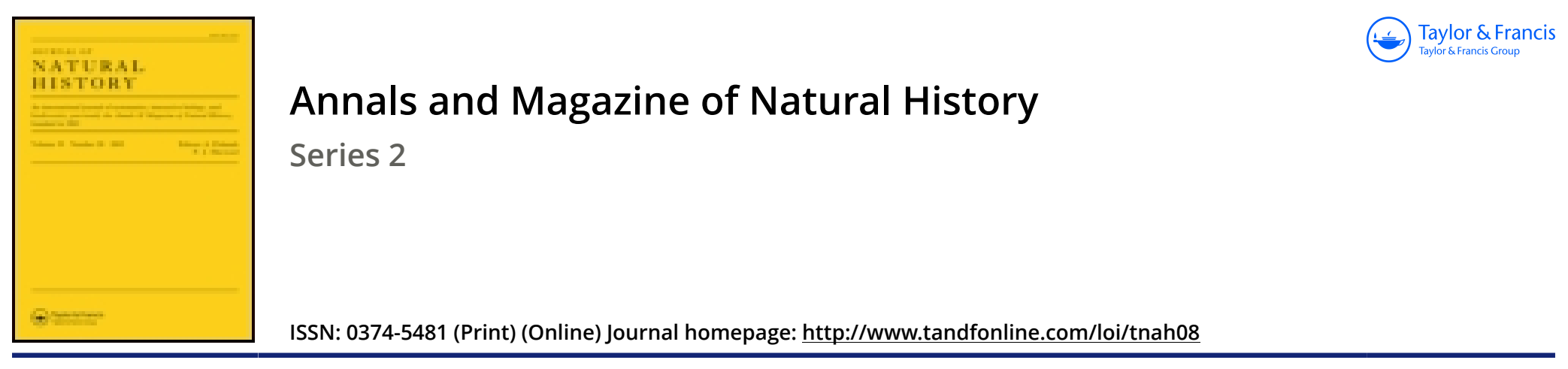

\title{
XXXIV.-Notice of a new species of Spiridens
}

\section{R.K. Greville LL.D.}

To cite this article: R.K. Greville LL.D. (1848) XXXIV.-Notice of a new species of Spiridens, Annals and Magazine of Natural History, 1:5, 325-326, DOI: $10.1080 / 03745485809496114$

To link to this article: http://dx.doi.org/10.1080/03745485809496114

$$
\text { 曲 Published online: } 21 \text { Dec } 2009 .
$$

Submit your article to this journal ๔

Џll Article views: 4

Q View related articles $\asymp$ 
The freshwater Mussel (Mya margaritifera, L.) is abundant in both the Dee and Don. The specimens in whose intestines the following Diatomacee occurred, were from the former river eighteen miles inland.

Meridiea.

Meridion circulare, $\mathbf{A g}$.

Fragilariea.

Fragilaria hyemalis, Lyngl.

Diatoma flocculosum, $A g$.

D. tenue, $\boldsymbol{A g}$.

Meloseirea.

Meloseira distans, Kütz.?

Surirellea.

Synedra capitata, Ehr.

S. tenuis, Kütz.

Cocconoidea.

Cocconeis Pediculus, Ehr.
Achnanthea.

Achnanthes minutissima, Ehr.

Cymbellea.

Cymbella flexella, Kütz.

C. leptoceras, Kü̈tz.?

Cocconema cymbiforme, Ehr.

Gomphonemea.

Gomphonema geminatum, $A g$.

G. pohliæforme, Kïttz.

G. minutum, $A g$.

Naviculea.

Navicula rhomboides, Ehr.?

N. cuspidata, $K \ddot{u} t z$.

N. viridis, Kütz.

Intermixed with these were spieulæ of Spongilla. Generally speaking the individuals of each species were of the minimum size, certainly far less than that usually attained. Of those brought within the sphere of the currents produced by the cilia, the smaller alone were swallowed. Of the species enumerated $I$ have found the following on our mountains at heights varying from 2800 to $\mathbf{3 8 0 0}$ feet : viz. Meridion circulare, Diatoma flocculosum, D. tenue, Meloseira distans?, Gomphonema pohliaforme, G. minutum, Navicula rhomboides? and N. viridis. The Meloseira I have found to constitute a considerable proportion of the fine black mud found beneath patches of snow on Ben-na-Muich Dhu.

XXXIV.- Notice of a new species of Spiridens. By R. K. Greville, LL.D. \&c.*

[With a Plate.]

THE genus Spiridens, established by Nees von Esenbeck in the 11th volume of the 'Nova Acta Acad. Cæs. Leopold. Car. Naturæ Curiosorum,' has hitherto contained the single species it was constituted to receive, viz. Spiridens Reinwardtii. This most noble of all mosses, as it is justly designated by Sir W. J. Hooker, is a native of the Molucca Isles ; twelve inches or more in height, with a robust, Bartramia-like habit. It is figured in the Transactions above-mentioned; but the British botanist will also find a figure and description in the first volume of Sir W. J. Hooker's 'Botanical Miscellany,' published in 1830.

- Head before the Botanical Society of Edinburgh, March 9, 1848. 
In looking over a small collection of Cryptogamous plants recently gathered in the island of Tahiti by Dr. Sibbald and sent by him to Professor Balfour, I found two specimens (only two, alas!) of a moss which a single glance convinced me must belong to the genus Spiridens; and the capsules being in a perfect state enabled me to determine this at once in the most satisfactory manner. The resemblance which it bears in general character to $S$. Reinwardtii is so marked, that at first it seemed doubtful whether it might not be a mere variety, but a more careful inspection rendered the specific distinctions quite apparent. The new species is a smaller and more slender plant, six to nine inches long or more, the leaves scarcely more than half the size, the capsules more cylindrical and the subulate termination of the operculum considerably longer and finer. It is under the microscope, however, that the most characteristic features are perceived to exist in the leaves; the margin of which in S. Reinwardtii is distinguished by a broad flat border closely and sharply toothed; in the new species by a very narrow thickened border remotely toothed. Without entering into a minute description, uncalled for in so brief a notice, the following specific characters may be assigned to the two mosses :-

S. Reinwardtii (Nees); foliis late marginatis, acute dentatis; dentibus approximatis; capsulis ovato-oblongis.

S. Balfouriana (nob.); foliis anguste marginatis, remote dentatis; capsulis ovato-cylindraceis.

This beantiful species of one of the finest genera in the family I have sincere pleasure in naming after my highly esteemed friend Dr. Balfour, Professor of Botany in the University of Edinburgh.

\section{EXPLANA'TION OF PLATE XVII.}

Fig. 1. S. Balfouriana, nat. size.

Fig. 2, Leaf.

Fig. 3. Margin of the leaf of S. Reinwardtii.

Fig. 4. Ditto of that of $S$. Balfouriana.

Fig. 5. Perichæetial leaves and capsule.

Fig. 6. Peristome.-Figs. 2-6 all magnified.

XXXV.-Notice of two new species of Ferns belonging to the genera Oleandra and Polypodium. By R. K. GREvilLe, LL.D. \&c.*

[With a Plate.]

Tre genus Oleandra of Cavanilles, adopted by Presl and now generally received for a section of the old genus Aspidium, is one

* Read before the Botanicul Society of Edinburgh, March 9, 1848. 


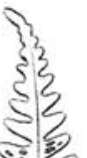

Ann.\& Mag. Nat. Hist. S.2. Vol.L. FI.XVIT.

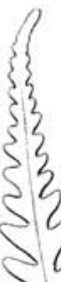

$\$ 2$

$\infty$

:3aze

195
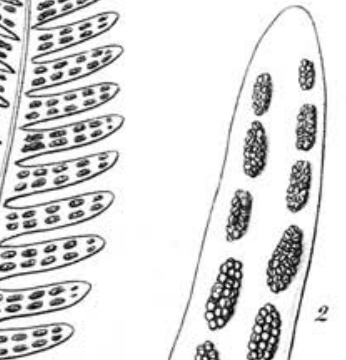

89

- :
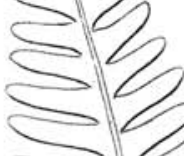

- $=890$

- S

in

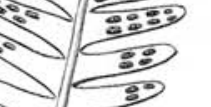

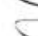
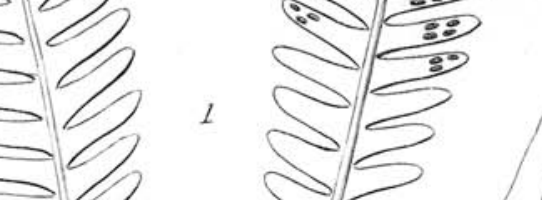

多

3

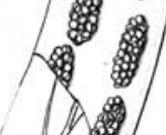

